\title{
Accidental Harm Under (Roman) Civil Law
}

\author{
Corjo Jansen
}

\begin{abstract}
A leading idea under Roman private law and nearly all European legal systems is that an owner has to bear the risk of an accidental loss (casus). An accident is a circumstance for which a third party cannot be blamed (culpa or fault). A person suffering damage from an accident had to bear that damage himself. This idea has been subject to attack throughout history. Every once in a while, it is said that 'bad luck must be righted' ('pech moet weg'). This position has not become the prevailing viewpoint among lawyers. Although it does not seem very realistic, 'bad luck must be righted' did form the basis of social security policies of the Netherlands and some other western countries after World War II: social security 'from womb to tomb'. The scope of social security benefits has been reduced in many countries in the last decades of the twentieth century, because the costs were no longer affordable. The idea that a owner has to bear the risk of casus has withstood the test of time quite well. That accidental harm must be borne by the one suffering it, is legally and morally justifiable.
\end{abstract}

\section{Introduction}

While engaging in activities, a person may suffer damage himself or, even worse, cause damage to someone else. An example for each situation is very easy to provide for. The first situation involves damage brought on by one's self: An individual slips and falls after a heavy rain shower and breaks a leg. The second situation involves damage brought on by another person: A bicyclist knocks down a pedestrian, who winds up with a broken arm. The moment at which the damage arises is often the point in time when the law comes into the picture. A significant task of the law is to formulate rules to specify in which cases damage must be

C. Jansen $(\bowtie)$

Legal History and Civil Law, Business and Law Research Centre, Radboud University,

Nijmegen, The Netherlands

e-mail: c.j.h.jansen@jur.ru.nl

(C) The Author(s) 2016

K. Landsman and E. van Wolde (eds.), The Challenge of Chance,

The Frontiers Collection, DOI 10.1007/978-3-319-26300-7_13 
compensated, for a person's freedom of action is not unlimited. The question arises whether someone who has suffered damage has to bear the loss himself or whether another person should bear liability for this.

A leading idea under the law is that the loss should lie where it falls. ${ }^{1}$ This notion reflects the old adage under Roman law, 'casum sentit dominus'. An owner has to bear the risk of an accidental loss or an accidental deterioration which has resulted in harm to him. ${ }^{2}$

This viewpoint has been criticised by, for example, the renowned German professor of Roman law, B. Windscheid (1817-1892): "Unbrauchbar und in dieser Allgemeinheit unrichtig (...)."3 Another prominent German scholar, H. Dernburg (1829-1907), was equally disapproving of the casum sentit dominus rule, stating: "Ihre Unhaltbarkeit wird (...) nicht leicht bestritten." And yet, under nearly all European legal systems, this rule appears to be authoritative. The legislator in Austria even laid it down in that country's civil code (\$1311 ABGB of 1811): "Der bloße Zufall trifft denjenigen, in dessen Vermögen oder Person er sich ereignet.",

The Roman law adage 'casum sentit dominus' is still important to day. The civil law systems of the Continent stem from Roman law. This law has become the intellectual ground for a largely homogenous legal culture on the Continent, based on the reception of Roman legal rules and principles. The two most important civil codes influenced by Roman law are the Code civil (Cc) of France (1804) and the Bürgerliches Gesetzbuch (BGB) of Germany (1900). Spain, Portugal, Belgium, the Netherlands, the former colonies of France and nearly the whole of South America have adopted the French $C c$. Greece and Japan adopted the German $B G B$. Contrariwise to the Continent, England developed an unique legal tradition. This tradition is called Common Law. Nearly $40 \%$ of all the people live in common law countries, like the United States of America, Australia, New Zealand, India, Pakistan and the other former colonies of England. Also the common law tradition has accepted the idea that loss should lie where it falls. That's why nearly all legal systems in the world know the adage 'casum sentit dominus'. In this article, the focus is on the Roman law tradition. ${ }^{6}$

An issue which crops up under Roman law (and thus under Continental civil law) is the meaning which needs to be given to the concept of 'casus' ('accident'). Roman-law sources suggest two meanings here. In the first instance, these sources teach, an 'accident' refers to some natural phenomenon ('act of God'), such as a

\footnotetext{
${ }^{1}$ Hartlief (1997); Sieburgh (2000); Markesinis and Deakin (2003), p. 42.

${ }^{2}$ Code of Justinian (C.) 4,24,9; Digests (D.) 50,17,23 (casus a nullo praestantur). See Wacke (1984), p. 271; Zimmermann (1996), pp. 154, 162, and 281; Sieburgh (2000), p. 5. Also referred to as 'res perit domino'.

${ }^{3}$ Windscheid and Kipp (1900), § 264, fn. 5: 'Useless and in this indefinite way wrong'.

${ }^{4}$ Dernburg (1903), p. 123, Note 3. For other examples, see Ranieri (2009), pp. 569-572.

${ }^{5}$ Wacke (1984), p. 670. Cf. Article 1105 Código Civil (Spanish Civil Code). In the Netherlands, see the Flood Damage Act 1953, Article 8:543 Dutch Civil Code and Article 8:1004(2) Dutch Civil Code.

${ }^{6}$ Zweigert and Kötz (1998), pp. 68-69, 218 et seq., 298; Zimmermann (2011), 27 et seq.
} 
lightning strike, flood, earthquake or compact impact. ${ }^{7}$ Further, an 'accident' may involve some misfortune, an unfortunate confluence of circumstances or 'allgemeine Lebensrisiko'.

To figure out the place 'casus' occupies under (Roman) private law, let's revisit my two earlier examples. If a person slips and falls after a heavy rain shower and breaks his leg, that person must bear the risk of his loss. The fact that the person slipped and fell is a risk which everyone runs in daily life. Another party cannot be made to pay for the damage. The situation might be different if an individual slips on a banana peel which was deliberately put on the floor. There is a very good chance in that case that someone else will be liable for the loss suffered. In the example where a pedestrian breaks his arm because of the bicyclist's actions, the question likewise arises whether the person suffering damage can hold someone else liable or not. The major reason for having another person foot the bill for the injury in the last two examples is that the injury can be traced back to the fault (culpa) of the persons causing the damage. The bicyclist bears blame for the pedestrian's broken arm, just as the person placing the banana peel on the floor can be blamed for the broken leg (liability without fault is also possible under the law, by the way, but I won't get into that here). "Fault is the basic element of the law of torts." ${ }^{\prime}$ In these examples, 'accident' stands in contrast to fault (in the sense of blameworthiness). ${ }^{9}$ Unlike with 'fault', the damage is not attributable to a person in the case of an 'accident'. By law, an accident is a circumstance for which a third party cannot be blamed or which is not attributable to someone.

Are there other meanings given to 'accident' which are relevant in (Roman) private law and which modify or expand the definition? In his inaugural lecture, De Mul, professor of philosophy in Rotterdam, argued that, under private law, the term 'accident' mainly signifies something being determined by fate and is often associated with such concepts as 'unforeseen' or 'unforeseeable'. ${ }^{10}$ I won't get into the first part of De Mul's definition. As to the second part, I note the following. For lawyers, concepts like 'unforeseen' and 'unforeseeable' are primarily factors in determining whether certain harm came about because of someone's fault. There is fault when what could have been foreseen by a diligent man was not foreseen. Fault entails someone's having acted differently than he should have, given the circumstances of the case. ${ }^{11}$ If that is so, he can be blamed for the harm. The meaning

\footnotetext{
${ }^{7}$ I won't get into the tricky distinction between casus and vis major (force majeure or 'scourge of God': D. 19,2,26,6). There is some overlap between the two terms. Coing (1989), p. 462, and Deroussin (2007), pp. 592-593.

${ }^{8}$ Owen (1995), pp. 201, 208-209, 223 et seq.; Atiyah (1997), p. 3; Zimmermann (1996), p. 1034; Markesinis and Deakin (2003), 41 et seq. Cf. D. 50,17,23.

${ }^{9}$ Bruins (1906), pp. 71-72; Rümelin (1896), p. 17; Von Bar (1999), Nos. 318-322, 485; Sieburgh (2000), 14 et seq.

${ }^{10}$ De Mul (1994), pp. 8-12, mentions two other basic connotations of 'accident': fortuitous (incidental or inessential) and contingent. See also Rümelin (1896), pp. 8-9 and 18.

${ }^{11}$ Cf. D. 9,2,31; Zimmermann (1996), pp. 1007-1009; Hartkamp and Sieburgh 6-IV* (2011), No. 100 .
} 
propounded by De Mul leaves the above definition of 'accident' intact. In Rümelin's words: "[Im Gegensatz zur Schuld spielt Zufall, das nicht Vorhergesehene und erfahrungsgemäss nicht Vorhersehbare] die Rolle eines Grenzbegriffs für irgend welche Verantwortlichkeit."12 Moreover, unintended consequences of people's conduct are often referred to as 'accidental' ${ }^{13}$ They, too, may be taken into account when assessing whether a certain action may be imputed to someone or not. Again, modifying the definition of 'accident' (in contrast to 'fault') does not seem necessary.

A brief digression about the sources of the obligation helps us to analyse the function of casus (accident) and culpa (fault) under (Roman) private law and the legal consequences which ensue from this. With regard to each Roman-law or other source, the notion of casus or culpa is, to a certain degree, developed differently.

\section{Sources of Obligation Under Roman and Modern Law}

An obligation to compensate another person's damage is not obvious. In his Institutes, the Roman lawyer Gaius (110-185 AD) distinguished two categories from which such an obligation might arise. "Every obligation arises either from contract or from wrongdoing." 14 The distinction between these two sources of obligation has withstood the test of time. It can also be seen in modern legal systems. Obligations to pay compensation do not, however, only arise from contract or wrongdoing. Gaius recognised this as well. In the second book passed down in his name, Res cottidianae sive aurea, Golden Words, Gaius added a third category as a source of obligation: "Obligations arise either from contract or from wrongdoing or, by some special right, from various types of causes." 15 What were examples of such another cause? Gaius talked about several of these in the third book of his Golden Words. One example was managing someone else's interest, negotiorum gestio ('agency without a mandate'). If someone looked after an absent person's affairs without having been instructed to do so, the two individuals became connected to each other and could litigate against one another based on the notion of management of another's affairs without authorisation. These legal actions did not arise from contract or wrongdoing. After all, the party managing the absent party's affairs had not concluded a contract with the absent party beforehand. Managing a person's affairs without a mandate was not a form of wrongdoing, either. ${ }^{16}$

\footnotetext{
${ }^{12}$ Rümelin (1896), p. 53.

${ }^{13}$ Rümelin (1896), p. 18; De Mul (1994), p. 12.

${ }^{14}$ Institutes of Gaius (Gai. Inst.) 3,88: (...): omnis enim obligatio vel ex contractu nascitur vel ex delicto.

${ }^{15}$ D. 44,7,1,pr.: Obligationes aut ex contractu nascuntur aut ex maleficio aut proprio quodam iure ex variis causarum figuris.

${ }^{16}$ D. $44,7,5, \mathrm{pr}$.
} 
The emperor Justinian (527-565) adopted the distinction from the Golden Words in his Institutes and changed it a little: "A further sub-classification results in four categories: specifically, obligations arising from contract, as if they were a contract (quasi-contract), or from delict, as if they were a delict (quasi-delict)." European legislators built upon Justinian's views in their legal codes. This also held true for the Dutch Civil Code of 1838. Under Article 1269 of this Code, all obligations resulted from either contract or the law [de wet]. Pursuant to Article 1388 Dutch Civil Code 1838, the latter category could in turn be sub-divided into obligations emanating "from the law alone or from the law as a result of human conduct". Obligations ensuing from the law due to people's conduct arose from "a lawful or an unlawful act" (Article 1389 Dutch Civil Code 1838). The provisions in Article 1269 Dutch Civil Code 1838 were criticised in the literature. In laying the foundations for the current Dutch Civil Code (1992), E.M. Meijers (1880-1954), professor of civil law in Leyde, tried to restore Gaius's definition. Meijers's original wording of Article 6:1 Dutch Civil Code stated that obligations arose from contract, tort or other juridical facts if these ensued from the law. He wanted to prevent obligations from rising outside the law based on the principle of reasonableness and fairness ('good faith') or based on unwritten law or custom. That simply produced legal uncertainty and legal inequality. ${ }^{18}$ Legislators after him looked to the Dutch Supreme Court's decision in Quint v Te Poel ${ }^{19}$ to formulate the sources of obligation under the new Dutch Civil Code. According to Article 6:1 Dutch Civil Code, obligations can only arise from the law. The words 'from the law', the Dutch Supreme Court explained, do not in any way mean that each obligation has to be expressly provided for by the law. In situations not provided for by law, the solution must be accepted "which fits into the statutory legal system and is in line with rules already laid down for similar situations." Still, Justinian's ancient Roman classification system lies behind the sparse wording of Article 6:1 Dutch Civil Code.

I will successively discuss the role of casus under Roman tort law, Roman contract law and Roman law concerning negotiorum gestio. ${ }^{20}$

\footnotetext{
${ }^{17}$ Institutes of Justinian (Inst.) 3,13,2: Sequens divisio in quattuor species diducitur: aut enim ex contractu sunt aut quasi ex contractu aut ex maleficio aut quasi ex maleficio. See also Inst. 4,5,pr. ${ }^{18}$ Asser, Hartkamp and Sieburgh 6-I* (2008), No. 47 et seq.

${ }^{19}$ Dutch Supreme Court (Hoge Raad), 30 January 1959, Nederlandse Jurisprudentie (NJ) 1959, 548.

${ }^{20}$ Casus does not come into play with quasi-delicts.
} 


\section{Accidental Harm Under Roman Tort Law and Subsequent Criticism}

The sources are very clear about the fact that, under Roman tort law, a person suffering damage from an accident had to bear that damage himself. Gaius contended that a party causing damage without fault or not intentionally, but instead by accident (casu), should remain 'unpunished'. ${ }^{21}$ The lawyer Alfenus (who lived in the first century before Christ) responded similarly when asked whether the owner of a slave who had broken his leg during a game after being pushed hard could litigate pursuant to the lex Aquilia, a statute reforming the law on wrongful damage to property by the Roman assembly of the plebs (the comitia centuriata) from 286 or $287 \mathrm{BC}$, named after the person who proposed it, the tribune Aquilius. Litigation was not possible, "[because] the unfortunate event needed to be deemed the result of an accident (casu) rather than fault." 22 This position has been subject to attack throughout history. The natural law scholar Chr. Thomasius (1655-1728) regarded 'you must not injure your neighbour' (alterum non laedere), a perspective which could also be found in the sources, ${ }^{23}$ as the guiding principle of tort law, from which he concluded that every damage ought to be compensated, even if it was caused by accident. "It is not only equitable but even just that I should make good damage done by accident." If, for instance, a person accidentally dropped someone's crystal glass, that person was, Thomasius felt, liable for the damage. It was his curiosity, not the owner's curiosity, which made the glass fall. ${ }^{24}$ Thomasius's position did not reflect the view of Roman lawyers. It has also not been embraced very much by today's lawyers. Every once in a while, it is said that 'bad luck must be righted' [pech moet weg], even if one can only blame one's self for it, but this is not the prevailing attitude. Lord Steyn, a justice of the current Supreme Court of the United Kingdom, articulated this feeling well:

"But we do not live in Utopia: we live in a practical world where the tort system imposes limits to the classes of claims that rank for consideration as well as to the heads of recoverable damages. This results, of course, in imperfect justice but it is by and large the best that the common law can do.",25

\footnotetext{
${ }^{21}$ Gai. Inst. 3,211: Itaque inpunitus est qui sine culpa et dolo malo, casu quodam damnum committit.

${ }^{22}$ D. 9,2,52,4: Respondi non posse, cum casu magis quam culpa videretur factum.

${ }^{23}$ D. $1,1,10,1$.

${ }^{24}$ Thomasius (2000), Sec. IV; Jansen (2009), 231 et seq.; Atiyah (1997), pp. 178-179. To his mind, the assumption that every type of loss ought to be compensated makes the compensatory system unaffordable.

${ }^{25}$ [1998] 3 WLR 1539B-C (per Lord Steyn).
} 


\section{Accidental Harm Under Roman Contract Law}

A contract usually involves two people: a debtor and a creditor. They must act with due care towards each other. The degree of care they need to exercise depends on the type of contract and the object to which the contract pertains (a horse, for instance, requires different care than a slave or painting). If debtors or creditors breach their duties of care, they will be liable for the ensuing damage. Here's an example. A person lends his bicycle to his neighbour ('the contract of commodatum'). The bicycle is stolen from the neighbour. Is the neighbour liable for this theft? This question cannot easily be answered. The crux of the issue is the scope of the neighbour's duty of care. Generally speaking, if a person does not exercise the requisite duty of care, he is at fault and is liable. Commodatum consisted of a gratuitous loan of a corporeal thing (mostly movables). The party borrowing the bicycle does not owe any money to the other party. Furthermore, lending out the bicycle is in the borrower's interest. Hence, Roman lawyers believed that the party who borrowed the bicycle, the neighbour in my example, had a very weighty duty of care ('custodia', or a duty of safekeeping). Because of this duty, the neighbour was liable to the lender of the bicycle in the event of theft. The borrower, who was responsible for custodia, had to therefore compensate the lender's damage, even though, subjectively, the borrower bore no blame.

This basic principle regarding commodatum did not automatically apply to other contracts. Some agreements merely entailed liability for intentional misconduct (dolus), others, for intentional misconduct (dolus) and fault (culpa), and still others, for intentional misconduct (dolus), fault (culpa) and custodia. The contract of mutuum received special treatment. Such a contract consisted of transferring ownership of a quantity of fungible goods (such as money or grain) to another party, who undertook to return an equal quantity of goods of the same sort. The most prominent example of a mutuum was the moneylending contract. The borrower became the owner of the goods. Consequently, the borrower bore the risk of destruction of the objects, even if this occurred by accident (casu fortuito), due to, say, fire, collapse, shipwreck or an attack by bandits or enemies. ${ }^{26}$ This principle was consistent with the rule that owners bear the risk of an accidental loss.

With other contracts, the required level of due care varied, but was never absolute. To quote the applicable Roman legislative text verbatim, "no one need bear responsibility for accidents and deaths occurring to living beings which are not attributable to anyone's fault, escapes by slaves usually left unguarded, or robberies, riots, fires, floods or attacks by bandits." 27 Such occurrences corresponded in large measure to 'acts of God' under English law. A borrower had to act with the utmost due care, for example. As we have seen, this meant, too, that the borrower was liable to the lender for theft. The borrower only avoided liability for events

\footnotetext{
${ }^{26}$ Inst. 3,14,2 and D. 44,7,1,4. See Wallinga (2009), p. 225 et seq.

${ }^{27}$ D. 50,17,23: (...) casus mortesque, quae sine culpa accidunt, (...) a nullo praestantur.
} 
which nobody could defend against (casus non praestat), such as attacks by bandits, enemies or pirates, fire and so on. ${ }^{28}$ As Schulz put it:

"[A borrower] was absolutely liable for certain typical accidents which were regarded as avoidable by properly watching and guarding the borrowed thing, and on the other hand he was not liable for other typical accidents which were invariably regarded as not avoidable by the exercise of care. ${ }^{29}$

A depositee who had offered to take possession of someone else's property was liable for intentional misconduct, negligence and custodia, but not for fortuitous events (casus fortuitos). ${ }^{30}$ A man who could show that he had lost his bookkeeping records on account of a shipwreck, collapse, fire or similar accident (alio simili casu) was not accountable to the banker from whom he had borrowed money. ${ }^{31}$ Likewise, losses incurred by accident (casu) were not chargeable to the balances which slaves had to pay their masters. ${ }^{32}$ In contrast, a mandatary could not seek reimbursement of his costs from the mandator if the mandatary had been robbed by bandits or had lost property during a shipwreck. These events were attributable to accident (magis casibusquam) rather than the mandate. ${ }^{33}$ If casus was involved, the party who had suffered damage thus bore this damage himself. There was no reason to shift the risk onto somebody else's shoulders.

\section{Accidental Harm in the Case of Negotiorum Gestio}

The idea of the management of another's affairs is a peculiarity under the law, since furnishing unsolicited help to another person is a precarious undertaking. Such conduct is readily seen as an undesirable interference or as a curtailment of someone's freedom. Under Roman law, no one was obliged to help another person. Nevertheless, there was a strong notion that citizens should help their fellow citizens in times of distress, by, for example, giving advice, providing a loan or voluntarily managing someone's interests without a mandate to do so. Schulz described 'management of another's affairs' as a "quite original genuinely Roman creation without parallels in the laws of other peoples not dependant on Roman Law."34

\footnotetext{
${ }^{28}$ D. $13,6,18$ pr. and D. $44,7,1,4$.

${ }^{29}$ Schulz 1969 , p. 515.

${ }^{30}$ D. 16,3,1,35. Zimmermann (1996), pp. 208-209. Such wide-ranging liability for a custodian is rather exceptional. It can be seen, too, in French law, but not in German law. Normally, a custodian is liable for dolus.

${ }^{31}$ D. $2,13,6,9$.

${ }^{32}$ D. $40,5,41,7$.

${ }^{33}$ D. 17,1,26,6; Zimmermann (1996), pp. 430-431.

${ }^{34}$ Schulz (1969), p. 624; Kortmann (2005), p. 99 et seq.; Jansen (2014), p. 43 et seq.
} 
The special nature of negotiorum gestio was also apparent in the manager's scope of liability; if an individual took care of the interests of an absent person who was unaware of this, the manager became liable for both wilful misconduct and negligence. A leading Roman lawyer maintained, however, that the party looking after the affairs even "had to answer for accident (casus), for example if in the name of the absent principal he transacts business the principal did not usually do." It goes without saying that such liability would be very extensive. Presumably, this far-reaching liability was prompted by the deep-seated aversion to representing someone's interests against the will of that person. ${ }^{35}$

\section{Other Meanings of 'Casus' in the Roman Sources}

'Casus' does not just mean 'accident' in the Roman-law sources. Sometimes, the word signifies 'misfortune', 'fate', 'adversity' or 'setback'. In these instances, it refers-just like in the case of accident - to an event resulting in damage which cannot be traced back to another party's fault. One text, for instance, categorises trees being uprooted or trees being blown over because of a storm as 'casus' ${ }^{36} \mathrm{~A}$ Roman lawyer used the word 'casus' in a similar sense, when he noted that it is neither decent nor natural to speculate about the misfortune or setback which a free man has suffered. ${ }^{37}$

'Casus' sometimes relates to destiny, say, to the fact that a person is deaf or blind. ${ }^{38}$ These meanings of 'accident' suggest something of the incomprehensibility or arbitrariness of life and the vicissitudes of fate (see De Mul's definition given in this article's introduction). 'Accident' here pertains not to human conduct, but to divine or similar intervention. It sets forth the limit of what lies within a person's control. $^{39}$

Finally, the Roman-law sources seem to imply that 'casus' also means 'independent of a person's will'. The law made it possible for giving rise of a legal consequence to hinge on a condition. Someone decided that the legal consequences would only arise if or until an uncertain future event took place (such as ownership not being transferred until the entire purchase price was paid). A slave, for example,

\footnotetext{
${ }^{35}$ D. 3,5,10; Zimmermann (1996), pp. 446-447. See also § 678 BGB (German Civil Code), which adopted this solution. The Dutch Supreme Court has embraced this position as well: Supreme Court, 19 April 1996, NJ 1997, 24.

${ }^{36}$ D. $7,1,12$,pr.

${ }^{37}$ D. $45,1,83,5$. See also D. 4,6,1,pr.

${ }^{38}$ D. $3,1,1,3$ and 5. See also D. 4,4,11,5.

${ }^{39}$ Eijsbouts (1989), pp. 2, 16, 19-20. See also the definition of 'treasure' in Article 642(2) Dutch Civil Code 1838 (Article 716 Code Civil (French Civil Code): a 'treasure' had to have been discovered by pure chance (le pur effet du hasard) (Eijsbouts (1989), pp. 6-7). In the current Article 5:13 Dutch Civil Code (a translation of $\S 984 B G B$ ), chance is no longer an element of the definition of treasure.
} 
might have been set free under a certain condition. This might have consisted of a fact, an action or one or another fortuitous circumstance (casu). ${ }^{40}$

\section{Brief Interlude: 'Casus' Under Roman Criminal Law}

Unlike in modern criminal law, 'casus' (by accident) is mentioned in the text of several Roman-law criminal provisions. The term had to do with the state of mind with which a crime was committed: with premeditation (proposito); in the heat of the moment (impetu) or by accident (casu, when, for example, a spear thrown at a wild animal during a hunt killed a man). ${ }^{41}$ The state of mind was relevant in determining the severity of the punishment. In the case of the more serious crimes, ascertaining whether these had been committed with premeditation or by accident (casus) was crucial, said the lawyer Ulpianus (who died in 223). For all crimes, this distinction had to result in either a just punishment or reduced punishment. ${ }^{42}$ Hence, according to the emperor Hadrian (117-138), the punishment for an individual who had committed manslaughter accidentally (casu) rather than intentionally (magis quam voluntate) during a scuffle was moderated. ${ }^{43}$ In modern criminal-law systems, intent, premeditation and negligence are the subjective elements of a crime. These days, casus is a factor in determining the degree of guilt which can be ascribed to accused individuals when they have engaged in potentially criminal conduct.

Accident always plays a role in criminal law to some extent. Whether certain punishable conduct must be characterised as an assault or as manslaughter depends on the consequence which ensues. Often, whether someone dies or is merely seriously injured as a result of a sharp blow to the face is a matter of accident. Potentially punishable conduct may likewise be nipped in the bud purely by accident; consider, for example, the case of a heavy rain shower which extinguishes a deliberately set fire. ${ }^{44}$

\footnotetext{
${ }^{40}$ D. $40,5,33,1$.

${ }^{41}$ D. $48,19,11,2$.

${ }^{42}$ D. $48,19,5,2$. See also D. $47,9,9$.

${ }^{43}$ D. $48,8,1,3$.

${ }^{44}$ Whether such an arson attempt constitutes a crime will depend on the circumstances of the case. See Dutch Supreme Court, 19 March 1934, NJ 1934, p. 350 (the Eindhoven arson judgment) and Dutch Supreme Court, 19 September 1977, NJ 1978, 126.
} 


\section{Accidental Harm Under Modern Private Law}

The viewpoints found in Roman law have-as stated above-often remained valuable for modern civil law. To the extent they still apply, the scope of their application must be determined. As we have seen, in Roman law, casus (in the sense of 'accident') played a role in contract law, the management of another's affairs and tort law. The force majeure doctrine ('non-attributable non-performance') has greatly diminished the role of accident in the area of contract law. Briefly stated, a situation of force majeure exists if the debtor, for reasons beyond his control, cannot fulfil his obligations. The failure of performance does not result from his fault and is not at his risk. Notwithstanding this development in modern private law, especially in the Dutch and German civil law, the $A B G B$ (Austrian Civil Code) and Código Civil (the Spanish Civil Code, 1889) still include - consistent with the Roman-law tradition-casus (accident) in addition to force majeure as a circumstance which frees debtors from their obligations ( $\$ 1447$ ABGB and Article 1105 Código Civil respectively). French courts still take accidental elements (l'aléa) into account as well. ${ }^{45}$

Almost all Continental legal systems look to the fault principle when a contract is not performed or not in a timely or proper manner: If a debtor cannot be blamed for the failure to perform, the debtor is not liable for damages. This principle was expanded in the Dutch Civil Code of 1992. Debtors can claim force majeure if performance is hindered for reasons for which they do not bear any fault and for which they do not bear the risk. ${ }^{46}$ The standard concerning the debtor's conduct is objective insofar as the debtor must have acted as a prudent debtor would have acted in the given situation ( $c f$. Article 6:27 Dutch Civil Code and $\S 276$ BGB). If the debtor has violated this objective standard, it must be examined whether the debtor can personally be blamed for this. If such personal blameworthiness (fault) is lacking, the question becomes whether the debtor is liable based on the law, juridical act or 'generally accepted principles'/common opinion (see Article 6:75 Dutch Civil Code). ${ }^{47}$ A person may invoke force majeure, for instance, if his life or liberty is threatened. Under generally accepted standards, the person is not liable then. For a comprehensive comparative-law analysis of fault and wilful or intentional misconduct in determining whether a debtor has breached his obligations towards the other party, I refer to Ranieri. ${ }^{48}$

Casus seems to play a larger role in modern tort law than in modern contract law. That is certainly true for the Netherlands. Whether a court must assume liability based on tort in a specific case will involve a weighing of the two viewpoints mentioned earlier which dominate this area of the law: 'the loss should lie where it

\footnotetext{
${ }^{45}$ Ranieri (2009), pp. 579-580, 584; Deroussin (2007), p. 594.

${ }^{46}$ Parlementaire Geschiedenis Boek 6 (1981), pp. 263-264; Hartkamp and Sieburgh 6-I* (2008), No. 343; Ranieri (2009), p. 572.

${ }^{47}$ Hartkamp and Sieburgh 6-I* (2008), No. 344.

${ }^{48}$ Ranieri (2009), pp. 572-650.
} 
falls' and 'you must not harm your neighbour'. The general consensus in Continental legal systems is that the maxim 'the loss should lie where it falls' must prevail if the damage arose through an accident, such as a failed harvest, flood or lightning strike. Even if the actions by a person resulting in damage actually come down to nothing more than an unfortunate confluence of circumstances, the party suffering that damage must bear that damage himself.

I mention a few examples. An old woman who wanted to get into a bus stepped back to allow someone to go in front of her. In stepping back, she bumped up against another old woman, who fell and broke her hip. A hiker in a forest kicked a branch. This branch lashed the eye of the hiker behind him. The hiker who got hit with the branch lost an eye. Two sisters were moving house. One of them lost her grip on a cabinet while going down the staircase. As a result, one sister's arm became wedged between the cabinet and the wall. The arm had to be amputated. ${ }^{49}$

In each of these situations, the conduct leading to harm cannot be said to have been improper or unlawful. What's more, the people in question can hardly be blamed for their conduct. The injury was related to an everyday risk, to the fact that we live and participate in society. These incidents are sometimes termed 'common or garden accidents'. The ensuing damage ought to remain where it fell. The risk did not exceed the general risk of damage which an individual runs in daily life. Further, the nature of the activity was not so dangerous that precautionary measures needed to be taken. ${ }^{50}$ Of course, the situation changes if a person's traits and abilities should have kept that person from participating in certain activities. "Just as it is ethically acceptable for people to claim personal credit for conduct which is partly a product of their good luck in having a certain personality and certain capacities, so people must accept responsibility for conduct which is partly a product of bad luck in having a certain personality and certain capacities."

\section{Concluding Observations}

Law and casus go back a long way. Accident was and is mainly important in answering the question whether certain damage must be borne by the party suffering the damage (the 'owner') or whether another party can be made to pay for this. This other party may be a natural person (the one causing the damage) or a legal entity (in particular, an insurance company). All of the Continental legal systems assume that damage arising by accident remains the responsibility of the party suffering the damage. For liability for the damage to be passed on to another

\footnotetext{
${ }^{49}$ Dutch Supreme Court, 11 December 1987, NJ 1988, 393; Dutch Supreme Court, 9 December 1994, NJ 1996, 403; and Dutch Supreme Court, 12 May 2000, NJ 2001, 300.

${ }^{50}$ Von Bar (1999), Nos. 319-320; Sieburgh (2000), 12 et seq.; Hartkamp and Sieburgh 6-IV* (2011), No. 20. Contrary view: Van Dam (2000), No. 808. See also Rümelin (1896), p. 12 et seq.

${ }^{51}$ Cane (1997), p. 51.
} 
party, the rule is and was that the damage must have been the fault of or attributable to that other party. The Roman-law adage 'casus sentit dominus' has withstood the test of time quite well. That accidental harm must be borne by the one suffering it is also morally justifiable. Owen expressed this as follows: "To the extent that risks of harm from action may be deemed a necessary part of 'proper' choices of action in an uncertain world, and hence 'reasonable' according to some fair standard, they should be viewed as 'background risks' of life for victims to protect against and bear." 52

Obviously, accident could be excluded as much as possible under private law. 'Bad luck must be righted' [pech moet weg] could be taken as the point of departure. Although this starting principle does not seem very realistic, it did form the basis of Dutch social security policy after World War II. The starving, humiliated and exhausted Dutch population expected a future in which socio-economic security was guaranteed for everyone and was no longer left to chance. This dream had to be realised by seeking high employment and an extensive system of social security and social welfare benefits. The Van Rhijn Commission (established on 7 April 1943 $)^{53}$ was the auctor intellectualis of this philosophy in the Netherlands. It articulated the following legal basis for a complete system of social security benefits encompassing the entire population:

"The community, organised in the form of the State, is responsible for the social security and protection against want of all of its members, provided that those members themselves do what is reasonable to furnish such social security and protection against want." ${ }^{, 54}$

The Van Rhijn Commission gained inspiration from overseas. Reports and plans in the United States and Great Britain served as models for the Dutch proposals. Winston Churchill (1874-1965) was instrumental here. Together with the American president Franklin Delano Roosevelt (1882-1945), he was the originator of the Atlantic Charter of 19 August 1941. That charter set out all sorts of freedoms, including 'freedom from want'. Such protection against want was intended to accomplish the following: "to bring about the fullest collaboration between all nations in the economic field, with the object of securing for all improved labour standards, economic advancement, and social security." The ideal here reflected the famous principle derived from Churchill, namely, 'social security from womb to tomb' ${ }^{55}$ This welfare state ideal was taken too far by some, who subscribed to the 'bad-luck-must-be-righted' notion and who wanted to shift any damage which a citizen might suffer primarily to the State (through social security, state funds, state

\footnotetext{
${ }^{52}$ Owen (1995), pp. 226-227.

${ }^{53}$ A.A. van Rhijn (1892-1986) was a secretary-general in several government departments (19331940), Minister of Agriculture and Fisheries (1940-1941) and Secretary-General at Social Affairs (1945-1950). His commission was responsible for providing a preliminary overview regarding the principles and main features of social security in the Netherlands.

${ }^{54}$ Social Security Report (1945) II, p. 10.

${ }^{55}$ Jansen and Loonstra (2013), pp. 269-270. A variation on this saying is 'from the cradle to the grave'.
} 
pensions and the like). This goal entails many risks, as "[p]eople who have grown up believing that the state would look always after them, no matter what misfortunes should strike, are now driven to find someone to sue, when they discover that the state will not and cannot deliver on this expectation."56

The scope of social security benefits has been reduced recently in countries such as the Netherlands. The costs were no longer affordable. The 'damage' was shifted too much to the community, so that the pressure on private insurance and tort law grew. ${ }^{57}$ Atiyah therefore argued that a no-fault system of liability should be developed for accidents and the personal harm ensuing from these and that a system of private and group insurance ought to be implemented for other cases of personal harm. ${ }^{58}$ In principle, insurance, which provides the right to a benefit if a particular contingent event occurs, is not concerned about the cause of the event. Whether the party entitled to the benefit was at fault is irrelevant. ${ }^{59}$ Atiyah's proposal, however, has hardly generated any response. The part of casus under modern private law has been anything but played out. The idea that the owner has to bear the consequences of 'accidents' is still very much alive in all Continental legal systems.

Open Access This chapter is distributed under the terms of the Creative Commons Attribution-Noncommercial 2.5 License (http://creativecommons.org/licenses/by-nc/2.5/) which permits any noncommercial use, distribution, and reproduction in any medium, provided the original author(s) and source are credited. The images or other third party material in this chapter are included in the work's Creative Commons license, unless indicated otherwise in the credit line; if such material is not included in the work's Creative Commons license and the respective action is not permitted by statutory regulation, users will need to obtain permission from the license holder to duplicate, adapt or reproduce the material.

\section{References}

Atiyah, P. S. (1997). The damages lottery. Oxford.

Bruins, G. W. J. (1906). Een onderzoek naar den rechtsgrond der schadevergoeding, diss. 's-Gravenhage.

Cane, P. (1997). The anatomy of tort law. Oxford.

Coing, H. (1989). Europäisches Privatrecht 1800 bis 1914, II (19. Jahrhundert). München.

De Mul, J. (1994). Toeval, inaugural lecture. Rotterdam.

Dernburg, H. (1903). Pandekten, $7^{\mathrm{e}}$ Auflage. Berlijn.

Deroussin, D. (2007). Histoire du droit des obligations. Parijs.

Eijsbouts, W. T. (1989). Recht en toeval. Premissen van 'het beleid' in het licht van de feiten, diss. Amsterdam.

For the Institutes of Gaius (Gai. Inst.), the Institutes of Justinian (Inst.), the Digests (D.) and the Code of Justinian (C.), the following were utilised: J. E. Spruit \& K. Bongenaar, De Instituten van Gaius, Second Edition, Zutphen 1994; J. E. Spruit, R. Feenstra \& K. E. M. Bongenaar

\footnotetext{
${ }^{56}$ Atiyah (1997), p. 176.

${ }^{57}$ Hartlief (1997), p. 72. I won't get into the role of strict liability.

${ }^{58}$ Atiyah (1997), p. 173 et seq.

${ }^{59}$ Hartlief (1997), p. 28.
} 
(red.), Corpus Iuris Civilis. Tekst en Vertaling, I, Zutphen/'s-Gravenhage 1993; J. E. Spruit, R. Feenstra \& K. E. M. Bongenaar (red.), Corpus Iuris Civilis. Tekst en Vertaling, II-VI, Zutphen/ 's-Gravenhage 1994-2001; J. E. Spruit, J. M. J. Chorus \& L. de Ligt (red.), Corpus Iuris Civilis. Tekst en Vertaling, VII-IX, Amsterdam 2005-2010.

Hartkamp, A. S., \& Sieburgh, C. H. (2008). Mr. C. Asser's Handleiding tot de beoefening van het Nederlandse Burgerlijk Recht, Verbintenissenrecht, De verbintenis in het algemeen, 6-I*, $13^{\mathrm{e}}$ druk. Deventer.

Hartkamp, A. S., \& Sieburgh, C. H. (2011). Mr. C. Assers Handleiding tot de beoefening van het Nederlands Burgerlijk Recht, Verbintenissenrecht, De verbintenis uit de wet, 6-IV*, $13^{\mathrm{e}}$ druk. Deventer.

Hartlief, T. (1997). Ieder draagt zijn eigen schade. Deventer.

Jansen, C. J. H. (2009). 'De lex Aquilia en de moderne onrechtmatige daad'. In K. J. Krzeminski en M.C.A. van den Nieuwenhuijzen (red.), De Digesten en de receptie van het Romeinse recht in het Nederlandse privaatrecht. Nijmegen, 231 sqq.

Jansen, C. J. H. (2014). 'Enkele historisch-vergelijkende beschouwingen over de grondslagen van de zaakwaarneming'. In L. van den Berge e.a. (red.), Historische Wortels van het Recht. Nijmegen, 41 sqq.

Jansen, C. J. H., \& Loonstra, C. J. (2013). 'De personele werkingssfeer van de sociale verzekeringswetten 1900-1960'. In C. J. H. Jansen en C. J. Loonstra, Opstellen over de historische ontwikkeling van het arbeidsrecht. Den Haag, 261 sqq.

Kortmann, J. (2005). Altruism in private law: Liability for nonfeasance and negotiorum gestio. Oxford: Oxford University Press.

Markesinis, B., \& Deakin, S. (2003). Markesinis and Deakin's Tort Law (5th ed.). Oxford: Oxford University Press.

Owen, D. G. (1995). 'Philosophical foundations of fault in Tort law'. In D. G. Owen (Ed.), Philosophical Foundations of Tort Law. Oxford.

Ranieri, F. (2009). Europäisches Obligationenrecht. Ein Handbuch mit Texten und Materialien, $3^{\mathrm{e}}$ Auflage. Wien/New York.

Rümelin, M. (1896). Der Zufall im Recht. Freiburg/Leipzig.

Schulz, F. (1969). Classical roman law. Oxford.

Sieburgh, C. H. (2000). Toerekening van een onrechtmatige daad, diss. Deventer.

Sociale Zekerheid, I-II. (1945). 's-Gravenhage.

Thomasius, C. (2000). Larva Legis Aquiliae [etc.] (M. Hewett, Ed., Trans.). Oxford/Portland: Oregon.

Van Dam, C. C. (2000). Aansprakelijkheidsrecht. Een grensoverschrijdend handboek, Den Haag.

Van Zeben, C. J. e.a. (red.). (1981). Parlementaire Geschiedenis van het Nieuwe Burgerlijk Wetboek, Boek 6 (Algemeen gedeelte van het verbintenissenrecht). Deventer.

Von Bar, C. (1999). Gemeineuropäisches Deliktsrecht, II. München.

Wacke, A. (1984). Gefahrerhöhung als Besitzerverschulden. Zur Risikoverteilung bei Rückgabepflichten im Spannungsfeld der Zurechnungsprinzipien casum sentit dominus, fur semper in mora und versari in re illicita. In G. Baumgärtel (u.A.) (Hrsg.) Festschrift für Heinz Hübner. Berlin/New York, 269 sqq.

Wallinga, T. (2009). Opzet, schuld en toeval. In K. J. Krzeminski en M. C. A. van den Nieuwenhuijzen (red.), De Digesten en de receptie van het Romeinse recht in het Nederlandse privaatrecht. Nijmegen, 215 sqq.

Windscheid, B. (1900). Lehrbuch des Pandektenrechts, II. Band, 8. Auflage, bearbeitet von Th. Kipp. Frankfurt.

Zimmermann, R. (1996). The Law of Obligations. Roman Foundations of the Civilian Tradition. South Africa/Deventer-Boston.

Zimmermann, R. (2011). Roman law and the Harmonization of Private Law in Europe. In A. Hartkamp et al. (Eds.), Towards a European civil code (4th ed.). Alphen aan den Rijn/Nijmegen, 27 sqq.

Zweigert, K., \& Kötz, H. (1998). Introduction to Comparative law (T. Weir, Trans.). Oxford. 